\section{Morbidity, utilization of curative care and service entry point preferences in metropolitan Centro Habana, Cuba}

\author{
Morbilidad, utilización de servicios terapéuticos y \\ preferencias en el punto de acceso a servicios de \\ salud en el área metropolitana de Centro de la \\ Habana, Cuba
}

\section{Morbidade, utilização de cuidados curativos e preferências de ponto de entrada aos serviços na área metropolitana de Centro Habana, Cuba}

Armando Rodríguez 1

Addys Díaz 1

Susana Balcindes 1

René García 1

Pol De Vos 2

Patrick Van der Stuyft 2,3

\begin{abstract}
First-line health services with a primary health care approach are a strong trigger for adequate health-care-seeking behavior. Research on the association between prevalence of chronic diseases and acute illnesses and use of health services emphasizes the importance of socioeconomic determinants in such patterns of utilization. In a cross-sectional study of 408 families in Centro Habana, Cuba, home interviews were conducted between April and June 2010 to analyze socio-demographic determinants of acute and chronic health problems and use of formal health services. Bivariate and logistic regression models were used. 529 persons reported a chronic disease. During the previous month, 155 of the latter reported an exacerbation and 50 experienced an unrelated acute health problem. 107 persons without chronic diseases reported acute health problems. Age was the strongest determinant of chronic disease prevalence. Adult women and the elderly were more likely to report acute problems. Acute patients with underlying chronic disease used formal services more often. No socio-demographic variable was associated with services use or consultation with the family physician. While the family physician is defined as the system's entry-point, this was the case for only 54\% of patients that had used formal services, thus compromising the physician's role in counseling patients and summarizing their health issues. The importance of chronic diseases highlights the need to strengthen the family physician's pivotal role. New economic policies in Cuba, stimulating self-employment and private initiative, may increase the strain on the exclusively public health care system. Still, the Cuban health system has demonstrated its ability to adapt to new challenges, and the basic premises of Cuba's health policy are expected to be preserved.
\end{abstract}

Chronic Disease; Health Services; Family Practice

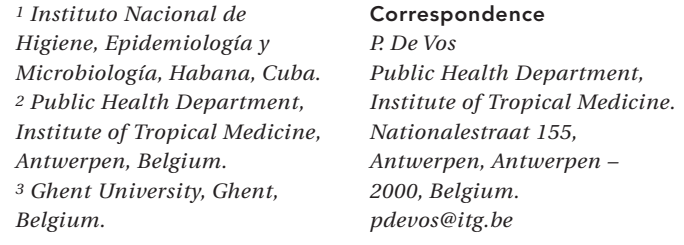

Instituto Nacional de Higiene, Epidemiología Microbiología, Habana, Cuba. 2 Public Health Department, Institute of Tropical Medicine, Antwerpen, Belgium. 3 Ghent University, Ghent, Belgium.

\author{
P. De Vos \\ Public Health Department, \\ Institute of Tropical Medicine. \\ Nationalestraat 155 \\ Antwerpen, Antwerpen - \\ 2000, Belgium. \\ pdevos@itg.be
}

Correspondence 


\section{Introduction}

Comprehensive first line health services that ensure geographical proximity for a defined population and that develop a stable relationship with patients and communities are essential for health system effectiveness and efficiency 1,2,3. Their organizational set-up has important implications for the community's behaviour towards all aspects of health, from promotion and disease prevention over health maintenance to the restoration of good health or the ability to adapt and to self-manage chronic conditions 4 . The Pan-American Health Organization (PAHO) underlines that the generalization to the whole of Latin America of first line health services with an adequate public health care (PHC) approach could avoid half of current hospitalizations 5 . Moreover, this type of first line health services are a strong trigger for adequate health-care-seeking behavior 6,7,8,9.

The analysis of factors influencing healthcare-seeking behavior helps to understand (and subsequently influence) patients' service preferences in terms of his or her personal needs and appreciation of the quality and resolution capacity of these services and their geographical, financial and cultural accessibility. In the literature most analyses of care seeking behavior are based on patients already accessing health services, or focusing on specific health problems or groups in the community, e.g. maternal health, hypertension in the elderly, etc 10,11,12,13. Community based studies that relate the prevalence of chronic diseases and acute sickness episodes in general to formal services utilization are less readily available. These studies emphasize the importance of economic and social determinants like professional activity and family income, transport ownership, insurance modalities, educational level and cultural beliefs, but seldom address service entry point preferences 14,15,16,17.

In the Cuban health system socio-economic barriers do not play a part. Health care is free at the point of care delivery, highly accessible and of good quality 18. A duo of a family doctor and a nurse care for a defined population of about 1,000 inhabitants. Their offices are located in the neighborhood served and the population for which they are responsible is well-defined. Comparable to the situation in Europe, family doctors are seen as the entry point for curative care. They coach and synthetize their patient's history in a personal and family file ${ }^{19}$. A link with the community is essential in this concept. Curative care is explicitly embedded in a comprehensive approach including health promotion, prevention and rehabilitation activities.
The family doctor is not the only entry point to the Cuban health system. A community policlinic (1 per 30,000 inhabitants) - conceptually seen as part of the first line services - not only delivers technical support and specialist back-stopping to the family doctors, but also has a 24 hour emergency service. Moreover, there is a referral hospital for every 150,000 inhabitants, also with emergency services. No financial or administrative access barrier exists to this level of care 20 .

Patients tend to use the nearby policlinic and hospital emergency services as alternative entry points, also for non-urgent ailments, particularly in urban areas, where distances between health care facilities are relatively small. This bypassing weakens the family doctor's accompanying role towards the patient 21 . Complementing earlier studies where we analyzed family doctor and emergency services use for perceived urgent problems 22,23, the present community based survey focusses on health care seeking behavior for health problems in general and chronic conditions in particular.

\section{Material and methods}

Dragones is a populous metropolitan neighbourhood in Centro Habana with approximately 7,500 families (32,000 inhabitants) in a territory of $0.5 \mathrm{~km}^{2}$. There is a policlinic and one family doctor practice per 1,000 inhabitants. Three general hospitals (two with second line care and one with tertiary care) are located at a distance of less than $3 \mathrm{~km}$.

In this cross sectional study, a systematic sample of 408 families was selected from an up to date list of all families in the area elaborated by the local health authorities. The sampling unit was a family (consisting of on average 3 members), and the unit of analysis was the individual. The sample size (408 families $\times 3$ members = 1,218 persons) was calculated to estimate the utilization of the family doctor as care entry point (a priori hypothesized to be around 50\%) with precision of $10 \%$ and a power of $80 \%$, taking a design effect of 2 , and assuming that on average one in six persons would have suffered from a health problem in the month previous to the survey. This sampling design (of including the whole family) was chosen to minimize bias of selecting the most sick or most healthy ones within each family.

A questionnaire was elaborated based on a literature review and previous experience and, prior to implementation in the area under study, it was validated in a pilot study conducted in another health area of the same municipality with 
similar demographic characteristics. Between April and June 2010, 13 well-trained and supervised lay pollsters interviewed the head of the family with a closed questionnaire during a home-visit. They collected information on all family members. In $78 \%$ of the interviews, other family members were present to assist recalling events and help answering the questions. When the family head was absent, a second visit was made in evening hours or in the weekend. After a second failed attempt, the next family on the list was selected. This happened only seven times. Every week, a supervisor reviewed the survey forms for information gaps or errors. When necessary, information was completed during a repeat visit by the same pollster.

Key questions related to self-reported health problems over the last month and to patient-initiated health system contacts for curative care. On the one hand, information was collected on the existence of a prevalent chronic disease, defined as a health problem lasting three months or more , and the occurrence of acute ailments or symptoms and/or of exacerbations of chronic problems over the last month (specific ailment, diagnosis, or health problem as formulated by the patient). On the other hand, the related health seeking behavior was ascertained (nothing, selfmedication, alternative health services, visits to the family doctor, the policlinic, the hospital), excluding scheduled routine controls. The visits to the family doctor, the policlinic and the hospital were categorized as "formal health service use". Alternative health services, i.e. healers linked to the Afro-Cuban religion, were only occasionally mentioned. They were categorized as "other action", together with self-medication.

Information was collected on individual socio-demographic variables, such as age, gender, educational level, professional activity and marital status. Professional activity was categorized as "not employed" for children, students, housewives, unemployed and retired persons, and as "employed" for persons earning a public/private sector income. The educational level variable was dichotomized into "up to secondary school level" (from 0 to 9 years of formal education) and "higher education" for persons having studied further after secondary school (i.e. technical school, pre-university or university).

Digital data entry was carried out using Access, and the data were analyzed with IBM SPSS Statistics 20 (IBM Corp., Armonk, USA). We analyzed the determinants of the prevalence of disease occurrence. Patient-initiated health system contacts for curative care were described in terms of service entry point and patient flow in the system, and determinants of formal service use and family doctor use were assessed. Bivariate analysis and logistic regression models were used on the study subsample of persons above 20 years only. Adjustments were made for the variables in the table. Possible interactions between variables were assessed.

Ethical approval of the study was obtained from the Instituto Nacional de Higiene, Epidemiología y Microbiología (INHEM) ethical review board. Informed consent was obtained from all interviewed persons. Information was made anonymous.

\section{Results}

\section{Population characteristics}

The 408 families included in the sample totaled 1,244 persons, an average of 3 persons per family (minimum 1, maximum 11), of which 505 (40.6\%) were men and 739 (59.4\%) women. Besides 408 heads of family (32.8\%), other members were the partner $(167,13.4 \%)$, children $(378,30.4 \%)$, and grandchildren $(144,11.6 \%)$. Parents, brothers/ sisters, nephews, grandparents and others accounted for less than $3 \%$.

The age of the population varied between 0 and 98 years, with an average of 40.8 years, and a median of 42 years $(\mathrm{Q} 1=23 \mathrm{y}$ and Q3 $=57 \mathrm{y})$. The groups below the age of 20 and over 65 represented $21.3 \%$ and $16.7 \%$ of the population respectively.

Of the 979 persons aged 20 years and older, 14 did not finish primary school (1.4\%), 64 finished primary school (6.5\%), 249 (25.4\%) finished secondary school, 218 (22.3\%) finished technical education, 246 (25.1\%) finished college ("pre-university"), and $188(19.2 \%)$ studied or study (3.2\%) at the university. $57.7 \%$ work for the government, $4.1 \%$ are self-employed. Moreover, we find $12.2 \%$ housewives, $20.4 \%$ retired and $2.6 \%$ unemployed.

\section{Health problems}

529 of the 1,244 persons (42.5\%) declared (or were reported) to have a chronic health problem (Figure 1), of whom 155 (29.3\%) had an exacerbation of the chronic condition over the last month. Moreover, 50 of these 529 (9.5\%) had an acute health problem. Of the 715 persons that were chronic disease free, 608 (85\%) experienced no health problem while 107 (15\%) had an acute problem. The elderly ( $p<0.001$ ) and women ( $p=0.003$ ) had significantly higher prevalence of chronic diseases than the other strata. Women also presented more acute health problems and 


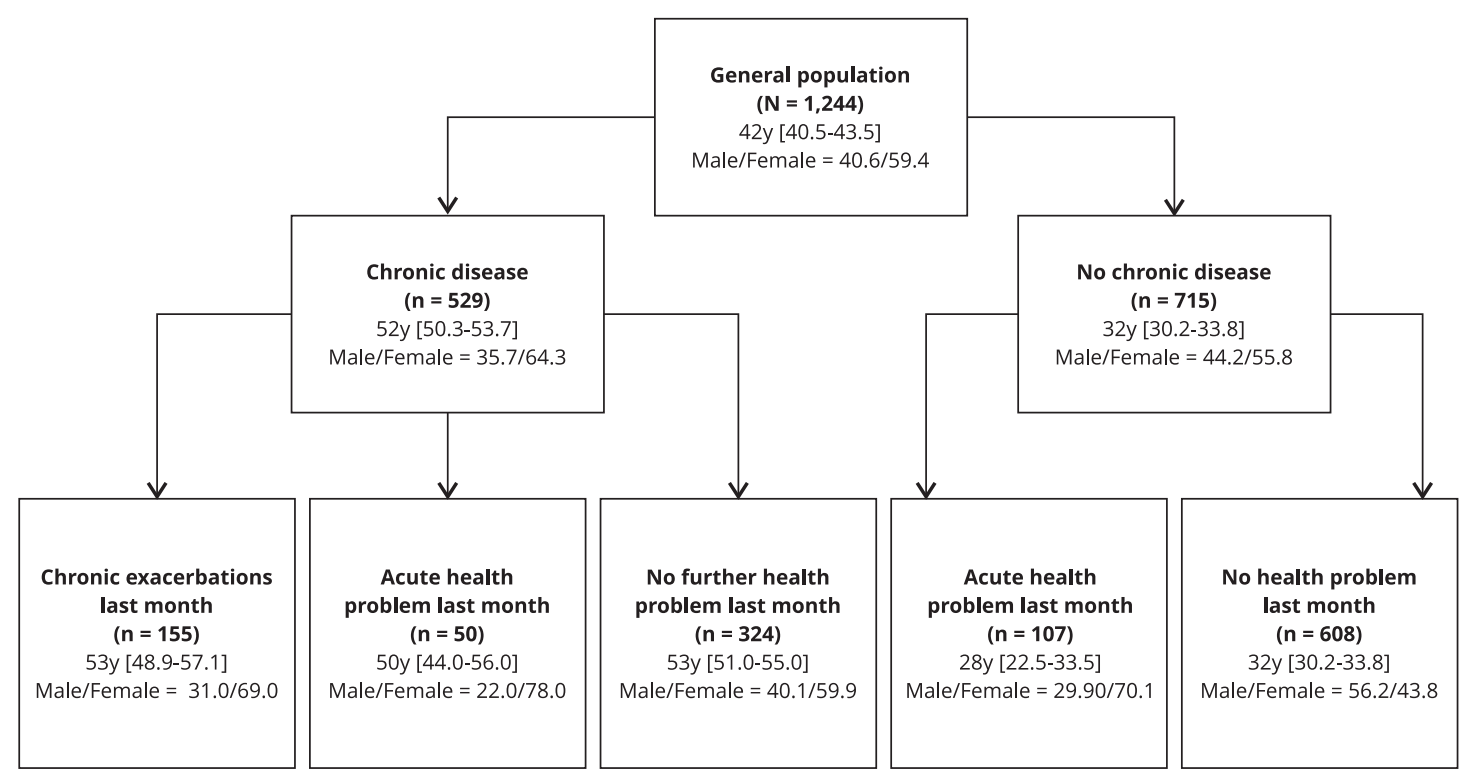

95\% Cl: $95 \%$ confidence interval.

exacerbations of chronic problems in the month previous to the survey ( $\mathrm{p}=0.015$ and $\mathrm{p}=0.001$ respectively), but there is no significant age difference $(\mathrm{p}=0.56$ and $\mathrm{p}=0.55$ respectively).

The main chronic problems mentioned were hypertension (188, $35.5 \%$ of total), asthma (99, $18.7 \%)$, diabetes $(77,14.6 \%)$, arthritis $(62,11.7 \%)$ and digestive problems $(44,8.3 \%)$, besides cancer (12, 2.3\%), cardiovascular diseases (20, 3.8\%) and mental problems $(15,2.8 \%)$, among others.

Table 1 identifies independent socio-demographic determinants of the prevalence of chronic diseases in the age group of 20 years and older. Women report more frequently suffering from a chronic ailment, as well as non-employed persons (including housewives and retired persons) and people with a lower educational level. Our results also illustrate the increasing burden of chronic diseases with age 24,25 .

In patients with a chronic disease (486) the main exacerbations over the last month are cardiovascular (60), respiratory (44), osteo-myo-articular (30) and endocrine (24) problems, while the acute diseases in this group were mainly respiratory (23), digestive (7), cardiovascular (7) and nervous system (6) problems. The patients without underlying chronic disease were mainly affected by respiratory (44), digestive (19) osteomyo-articular (10), gynecological (9) and urinary (8) problems.

The most frequent acute symptoms in the non-chronic and chronic subgroup respectively, are headache $(38,35.5 \%$ and $18,36 \%)$, fever $(46$, $43 \%$ and $10,20 \%)$, pain $(19,17.8 \%$ and $10,20 \%)$, and diarrhea (13, $12 \%$ and $4,8 \%)$.

Table 2 presents the independent determinants of the occurrence of chronic exacerbations and acute problems for adult patients with an underlying chronic disease. Having a chronic exacerbation is associated with higher education and being single. Women suffered more frequently from an acute health problem.

Table 3 presents the same analysis for the adult population without chronic problems. We found a significantly higher frequency of acute illness in women. No significant relation was found with age, educational level, occupation or marital status.

Overall, 137 persons (43.9\% of 312 ) suspended work or study activities because of their disease during the last month before the interview, $57.3 \%$ of the patients with an acute ailment and $30.3 \%$ of those with a chronic exacerbation $(\mathrm{p}<0.0001)$. 
Table 1

Determinants of the prevalence of a chronic disease in the population $\geq 20$ years. Centro Habana, Cuba, $2010(n=979)$

\begin{tabular}{|c|c|c|c|}
\hline & Prevalence of chronic disease & Crude OR $(95 \% \mathrm{Cl})$ & Adjusted OR $(95 \% \mathrm{Cl})$ \\
\hline \multicolumn{4}{|l|}{ Gender } \\
\hline Male & $44.4(174 / 392)$ & 1.00 & 1.00 \\
\hline Female & $53.2(312 / 587)$ & $1.42(1.10-1.84)$ & $1.56(1.18-2.08)$ \\
\hline \multicolumn{4}{|l|}{ Education } \\
\hline Up to secondary school level & $66.4(217 / 327)$ & 1.00 & 1.00 \\
\hline Higher education & $41.3(269 / 652)$ & $0.36(0.27-0.47)$ & $0.66(0.48-0.91)$ \\
\hline \multicolumn{4}{|l|}{ Occupation } \\
\hline Not employed & $69.1(177 / 256)$ & 1.00 & 1.00 \\
\hline Employed & $42.7(309 / 723)$ & $0.33(0.25-0.45)$ & $0.60(0.41-0.90)$ \\
\hline \multicolumn{4}{|l|}{ Marital status } \\
\hline Single/Divorced/Widow & $48.8(214 / 441)$ & 1.00 & \\
\hline Union/Married & $50.4(271 / 538)$ & $1.07(0.83-1.37)$ & \\
\hline \multicolumn{4}{|l|}{ Age (years) } \\
\hline $20-44$ & $28.1(114 / 405)$ & 1.00 & 1.00 \\
\hline $45-64$ & $57.9(212 / 366)$ & $3.51(2.60-4.74)$ & $3.47(2.55-4.73)$ \\
\hline$\geq 65$ & $76.9(160 / 208)$ & $8.51(5.77-12.55)$ & $5.16(3.19-8.36)$ \\
\hline
\end{tabular}

95\% Cl: 95\% confidence interval; OR: odds ratio.

Table 2

Determinants of the occurrence of health problems (chronic exacerbations or acute health problem in the last month) in adults with an underlying chronic disease. Centro Habana, Cuba, 2010 ( $n=486$ ).

\begin{tabular}{|c|c|c|c|c|c|c|}
\hline & \multicolumn{3}{|c|}{ Chronic exacerbation } & \multicolumn{3}{|c|}{ Acute health problem } \\
\hline & $n(\%)$ & Crude OR $(95 \% \mathrm{Cl})$ & Adjusted OR $(95 \% \mathrm{Cl})$ & n (\%) & Crude OR $(95 \% \mathrm{Cl})$ & Adjusted OR $(95 \% \mathrm{Cl})$ \\
\hline \multicolumn{7}{|l|}{ Gender } \\
\hline Male & $41(25.2)$ & 1.00 & 1.00 & $11(8.3)$ & 1.00 & 1.00 \\
\hline Female & $97(35.1)$ & $1.61(1.05-2.48)$ & $1.48(0.94-2.32)$ & $36(16.7)$ & $2.23(1.09-4.55)$ & $2.09(1.01-4.33)$ \\
\hline \multicolumn{7}{|l|}{ Education } \\
\hline $\begin{array}{l}\text { Up to secondary school } \\
\text { level }\end{array}$ & $52(26.4)$ & 1.00 & 1.00 & $20(12.1)$ & 1.00 & 1.00 \\
\hline Higher education & $86(35.5)$ & $1.54(1.02-2.32)$ & $1.89(1.18-3.02)$ & $27(14.8)$ & $1.25(0.67-2.33)$ & $1.16(0.59-2.28)$ \\
\hline \multicolumn{7}{|l|}{ Occupation } \\
\hline Not employed & $50(30.9)$ & 1.00 & 1.00 & $15(11.8)$ & 1.00 & 1.00 \\
\hline Employed & $88(31.8)$ & $1.04(0.69-1.58)$ & $1.32(0.73-2.40)$ & $32(14.5)$ & $1.26(0.66-2.44)$ & $1.11(0.47-2.64)$ \\
\hline \multicolumn{7}{|l|}{ Marital status } \\
\hline Single/Divorced/Widow & $74(38.3)$ & 1.00 & 1.00 & $22(15.6)$ & 1.00 & 1.00 \\
\hline Union/Married & $64(26.0)$ & $0.56(0.38-0.85)$ & $0.61(0.40-0.94)$ & $25(12.1)$ & $0.74(0.40-1.38)$ & $0.84(0.45-1.59)$ \\
\hline \multicolumn{7}{|l|}{ Age (years) } \\
\hline $20-44$ & $35(35.0)$ & 1.00 & 1.00 & $14(17.7)$ & 1.00 & 1.00 \\
\hline $45-64$ & $53(27.6)$ & $0.71(0.42-1.19)$ & $0.82(0.48-1.40)$ & $20(12.6)$ & $0.67(0.32-1.41)$ & $0.74(0.35-1.59)$ \\
\hline$\geq 65$ & $50(34.0)$ & $0.96(0.56-1.63)$ & $1.62(0.78-3.37)$ & $13(11.8)$ & $0.62(0.27-1.41)$ & $0.79(0.28-2.24)$ \\
\hline
\end{tabular}

95\% $\mathrm{Cl}$ : 95\% confidence interval; OR: odds ratio. 
Determinants of the occurrence of an acute health problem in the last month, in adults without underlying chronic disease. Centro Habana, Cuba, 2010 ( $n=493)$.

\begin{tabular}{|c|c|c|c|}
\hline & n (\%) & Crude OR (95\%Cl) & Adjusted OR (95\% Cl) \\
\hline \multicolumn{4}{|l|}{ Gender } \\
\hline Male & $16(7.3)$ & 1.00 & 1.00 \\
\hline Female & $50(18.2)$ & $2.81(1.55-5.08)$ & $2.86(1.56-5.25)$ \\
\hline \multicolumn{4}{|l|}{ Education } \\
\hline Up to secondary school & $19(17.3)$ & 1.00 & 1.00 \\
\hline Higher education & $47(12.3)$ & $0.67(0.37-1.20)$ & $0.97(0.49-1.93)$ \\
\hline \multicolumn{4}{|l|}{ Occupation } \\
\hline Not employed & $13(16.5)$ & 1.00 & 1.00 \\
\hline Employed & $53(12.8)$ & $0.75(0.39-1.44)$ & $0.90(0.42-1.93)$ \\
\hline \multicolumn{4}{|l|}{ Marital status } \\
\hline Single/Divorced/Widow & $33(14.6)$ & 1.00 & 1.00 \\
\hline Union/Married & $33(12.4)$ & $0.83(0.49-1.39)$ & $0.89(0.52-1.55)$ \\
\hline \multicolumn{4}{|l|}{ Age (years) } \\
\hline $20-44$ & $34(11.7)$ & 1.00 & 1.00 \\
\hline $45-64$ & $21(13.6)$ & $1.19(0.66-2.14)$ & $1.32(0.72-2.42)$ \\
\hline$\geq 65$ & $11(22.9)$ & $2.25(1.05-4.82)$ & $2.26(0.88-5.84)$ \\
\hline
\end{tabular}

95\% Cl: 95\% confidence interval; OR: odds ratio.

\section{Health seeking behavior}

Persons with acute and exacerbations of chronic problems undertook the following actions: 27 patients did nothing $(10,6.4 \%$ and $17,11 \%$ respectively), 72 patients only used self-medication (36, $22.9 \%$ and $36,23.2 \%$ ), while 213 consulted a formal health service - family doctor, policlinic or hospital (111, 70.7\% and 102, 65.8\%).

In the age group below 20 years, $79.5 \%$ and $64.7 \%$ used a formal service for an acute problem and a chronic exacerbation, respectively. Table 4 details the determinants of formal health services use in function of the patients' characteristics for the 251 adult persons with a health problem over the last month. The group above 64 years used a formal service slightly more frequently than the other age groups, although this difference is not statistically significant $(p=0.11$ and $p=0.43$ for acute problem and chronic exacerbation respectively). Specifically for acute ailments, patients with an underlying chronic disease make more use of formal health services $(\mathrm{OR}=2.56$; $95 \% \mathrm{CI}$ : 1.09-6.01). After controlling for confounding (by age, gender, education, employment and marital status), use of formal health services for acute health problems is only influenced by the existence of an underlying chronic disease $(\mathrm{OR}=$ 2.03; 95\%CI: 0.91-4.52; $\mathrm{p}$-value $=0.08$ ). In adults with an exacerbation of a chronic disease, the use of formal health services is less frequent in the group of married persons $(\mathrm{OR}=0.44$; $95 \% \mathrm{CI}$ : 0.22-0.91), but after controlling for confounding none of these characteristics remained significantly associated with the use of formal services.

Of the 312 patients who were sick over the last month before interview, patients who had 7-14 days of sick leave were more likely to go to formal health services (OR $=0.247$; 95\%CI: 0.080-0.762). Also patients with more than two (acute and/or chronic) health problems at the same time were more likely to contact formal health services (OR= 0.333; 95\%CI: 0.146-0.763).

\section{Entry point to and patient flow in the formal health system}

Figure 2 gives an overview of the entry point to the formal health system and the subsequent flow within the system. For the patients with acute and chronic ailments that used formal services, the family doctor was the entry point for 65 (58.6\%) and 50 (49\%) patients respectively. Alternative entry points were the policlinic (specifically the emergency services of the policlinic) for $16(14.4 \%)$ acute and 20 (19.6\%) chronic cases and the hospital for $30(27 \%)$ acute and 32 (31.4\%) chronic cases. Referral by the family doctor of acute patients was limited $(6.2 \%)$ while $24 \%$ of the chronic patients were referred. The family 
Determinants of using formal health services in adults with a health problem. Centro Habana, Cuba, 2010 ( $n=251)$.

\begin{tabular}{|c|c|c|c|c|}
\hline & \multicolumn{2}{|c|}{$\begin{array}{l}\text { Acute problem } \\
\qquad[n=113]\end{array}$} & \multicolumn{2}{|c|}{$\begin{array}{l}\text { Chronic exacerbation } \\
\qquad[\mathrm{n}=138]\end{array}$} \\
\hline & $\begin{array}{l}\text { Formal service use } \\
\qquad[n=76](\%)\end{array}$ & Crude OR $(95 \% \mathrm{Cl})$ & $\begin{array}{l}\text { Formal service use } \\
\qquad[n=91](\%)\end{array}$ & Crude OR $(95 \% \mathrm{CI})$ \\
\hline \multicolumn{5}{|l|}{ Gender } \\
\hline Male & $21(77.8)$ & 1.00 & $22(53.7)$ & 1.00 \\
\hline Female & $55(64.0)$ & $0.51(0.18-1.39)$ & $69(71.1)$ & $2.13(1.00-4.53)$ \\
\hline \multicolumn{5}{|l|}{ Education } \\
\hline Up to secondary school level & $27(69.2)$ & 1.00 & $37(71.2)$ & 1.00 \\
\hline Higher education & $49(66.2)$ & $0.87(0.38-2.00)$ & $54(62.8)$ & $0.68(0.33-1.44)$ \\
\hline \multicolumn{5}{|l|}{ Occupation } \\
\hline Not employed & $19(67.9)$ & 1.00 & $35(70.0)$ & 1.00 \\
\hline Employed & $57(67.1)$ & $0.96(0.39-2.40)$ & $56(63.6)$ & $0.68(0.33-1.44)$ \\
\hline \multicolumn{5}{|l|}{ Marital status } \\
\hline Single/Divorced/Widow & $34(61.8)$ & 1.00 & $55(74.3)$ & 1.00 \\
\hline Union/Married & $42(72.4)$ & $1.62(0.73-3.58)$ & $36(56.3)$ & $0.44(0.22-0.91)$ \\
\hline \multicolumn{5}{|l|}{ Age (years) } \\
\hline $20-44$ & $30(62.5)$ & 1.00 & $23(65.7)$ & 1.00 \\
\hline $45-64$ & $26(63.4)$ & $1.04(0.44-2.47)$ & $31(58.5)$ & $0.74(0.30-1.78)$ \\
\hline$\geq 65$ & $20(83.3)$ & $3.00(0.88-10.18)$ & $37(74.0)$ & $1.48(0.58-3.81)$ \\
\hline \multicolumn{5}{|l|}{ Underlying chronic health problem } \\
\hline No & $39(59.1)$ & 1.00 & n.a. & n.a. \\
\hline Yes & 37 (78.7) & $2.56(1.09-6.01)$ & n.a. & n.a. \\
\hline
\end{tabular}

95\% Cl: 95\% confidence interval; n.a.: not applicable; OR: odds ratio.

doctor was the only contact (i.e. without any further referral) for $55 \%$ of acute patients and $37.2 \%$ of chronic patients $(p=0.01)$. Health seeking behavior in the formal health system (comparing use of family doctor and of hospital/policlinic as entry point) was not significantly different for acute and chronic problems $(\mathrm{p}=0.16)$.

For adult patients, the choice for the family doctor or the policlinic/hospital as entry point for a chronic exacerbation is associated with gender - men were found to visit a family doctor four times less frequently than women $(\mathrm{OR}=$ 0.27; 95\%CI: 0.09-0.78) - and with marital status - single/divorced/widow persons are visiting a family doctor three times more frequently than married persons $(\mathrm{OR}=3.24$; 95\%CI: $1.34-7.81)$ (Table 5). This association was not significant any more after controlling for confounding. For acute health problems in adults, there is no significant association of family doctor use with the studied socio-demographic variables.

$76.9 \%$ (95\%CI: $54.0-99.8$ ) of the patients with diarrhea and 64\% (95\%CI: 48.2-79.6) with an acute respiratory infection consult the family doctor first. Also in chronic diseases the family doctor is the most important entry point: $62.2 \%$ (95\%CI: 46.5-77.8) for hypertension and 65\% for diabetes (95\%CI: 44.1-85.9). In contrast, for asthma this figure is only $21.7 \%$ (95\%CI: $4.9-38.6$ ).

\section{Discussion}

This study analyses the health seeking behavior in a metropolitan setting in Cuba, where different entry points - at different levels of care - coexist at walking distance. Analyzing strengths and weaknesses of this study at family level, we consider having obtained a strong quantitative and qualitative response. This achievement was realized through well-trained and well-supervised voluntary health promotors. As they have sufficient basic knowledge on health, and are trusted by their neighbors, they could ensure adequate information gathering. Nevertheless, self-reported information might have its weaknesses, one of them being a possible recall bias. To minimize this risk, the recall period was limited to one month. The sample size for some subgroups was rather small for advanced multi- 
2a) Acute health problems $(n=111)$

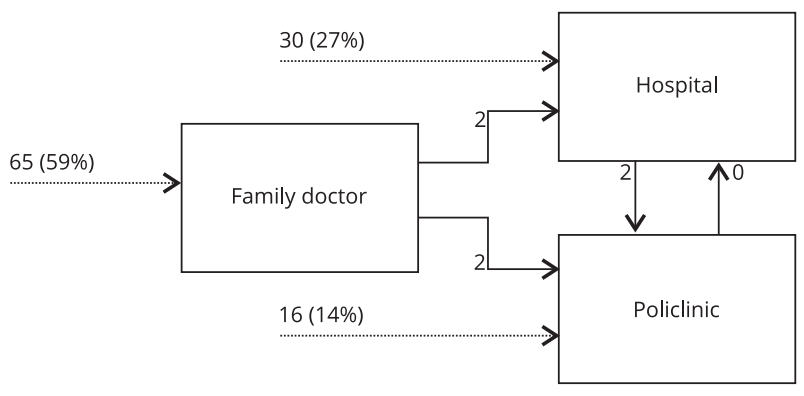

2b) Chronic health problems $(n=102)$
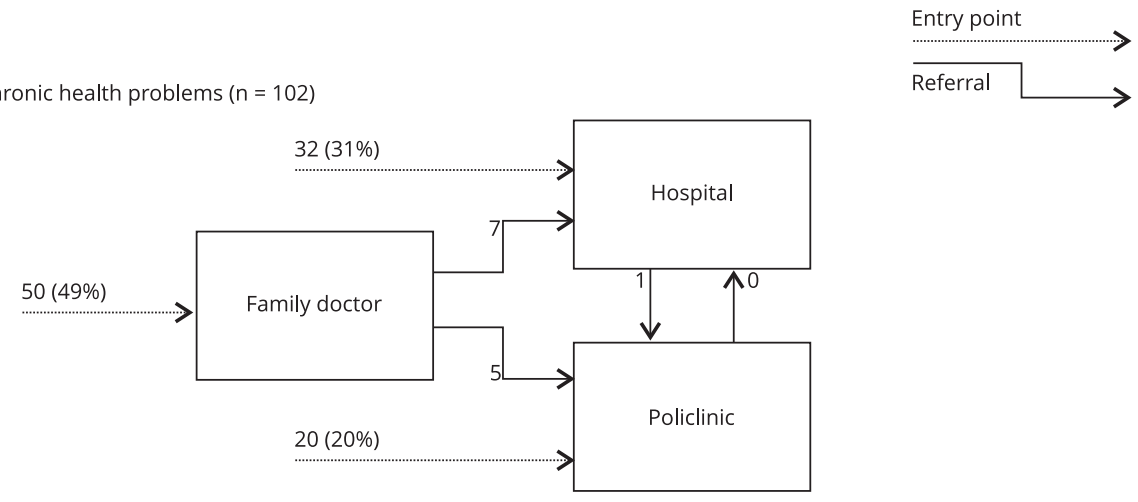

variate analysis. Nevertheless meaningful results were obtained.

The sex ratio in our study population is in line with the composition of the population of Dragones ( $43 \%$ men and $57 \%$ women), and reflects male out migration to other regions of Cuba and abroad, and the higher life expectancy of women.

We found $48.5 \%$ of the population to be active, somewhat higher than the official figure of $44.7 \%$ for the whole country (which is comparable to that of Colombia at $45.5 \%$ or Venezuela at 45.7\%) (International Labour Office. LABORSTA. http://laborsta.ilo.org/). The occupation pattern reflects the societal organization of a metropolitan area in socialist Cuba: almost $60 \%$ of the active population is working in the public sector (administration, production, services), while only a limited number of people is self-employed, and official unemployment it at a low $2.6 \%$. These figures might change dramatically in the coming years as the Cuban government opted in 2011 for reducing the number of state employees and is developing policies to encourage self-employment (Documentos VI Congreso del Partido
Comunista de Cuba. http://congresopcc.cip.cu/ congresos/vi-congreso-pcc).

\section{Health problems}

A rather high $51.1 \%$ of the population reported having health problems. Half had a chronic disease without any complaint over the last month, the other half was equally divided between acute and chronic ailments. While women have more acute illnesses, older persons refer more chronic problems. In addition to diarrhea and respiratory infections, patients described acute health problems mainly as symptoms like fever or pain. Chronic problems had a more precise diagnosis.

The actual Cuban demographic characteristics lead to one of the most rapid and profound aging processes of the Americas and the world 26 This implies that chronic ailments are expected to increase in frequency and importance. Consequences in terms of workload and care characteristics should be anticipated by an adequate (re) organization of health care. 
Determinants of using the family doctor's as entry point (conditional on formal health service use) in adults with a health problem. Centro Habana, Cuba, 2010 $(n=167)$.

\begin{tabular}{|c|c|c|c|c|c|c|}
\hline & \multicolumn{3}{|c|}{ Chronic exacerbation [ $n=91]$} & \multicolumn{3}{|c|}{ Acute health problem $[n=76]$} \\
\hline & $\begin{array}{c}\text { Family } \\
\text { doctor's } \\
{[n=46](\%)}\end{array}$ & Crude OR $(95 \% \mathrm{Cl})$ & $\begin{array}{l}\text { Adjusted OR } \\
\qquad(95 \% \mathrm{Cl})\end{array}$ & $\begin{array}{l}\text { Family doctor's } \\
\text { [n = 47] (\%) }\end{array}$ & Crude OR $(95 \% \mathrm{Cl})$ & $\begin{array}{l}\text { Adjusted OR } \\
\qquad(95 \% \mathrm{Cl})\end{array}$ \\
\hline \multicolumn{7}{|l|}{ Gender } \\
\hline Male & $6(27.3)$ & $0.27(0.09-0.78)$ & $0.38(0.12-1.17)$ & $10(47.6)$ & $0.44(0.16-1.23)$ & $0.44(0.15-1.35)$ \\
\hline Female & $40(58.0)$ & 1.00 & 1.00 & $37(67.3)$ & 1.00 & 1.00 \\
\hline \multicolumn{7}{|l|}{ Education } \\
\hline $\begin{array}{l}\text { Up to secondary school } \\
\text { level }\end{array}$ & $23(62.2)$ & $2.21(0.91-5.21)$ & $1.56(0.57-4.40)$ & $14(51.9)$ & $0.52(0.20-1.37)$ & $0.52(0.17-1.60)$ \\
\hline Higher education & $23(42.6)$ & 1.00 & 1.00 & $33(67.3)$ & 1.00 & 1.00 \\
\hline \multicolumn{7}{|l|}{ Occupation } \\
\hline Not employed & $20(57.1)$ & $1.54(0.66-3.60)$ & $1.54(0.47-5.08)$ & $11(57.9)$ & $0.80(0.28-2.31)$ & $1.90(0.40-9.11)$ \\
\hline Employed & $26(46.4)$ & 1.00 & 1.00 & $36(63.2)$ & 1.00 & 1.00 \\
\hline \multicolumn{7}{|l|}{ Marital status } \\
\hline Single/Divorced/Widow & $34(61.8)$ & $3.24(1.34-7.81)$ & $2.42(0.88-6.69)$ & $20(58.8)$ & $0.79(0.31-2.01)$ & $0.92(0.32-2.69)$ \\
\hline Union/Married & $12(33.3)$ & 1.00 & 1.00 & $27(64.3)$ & 1.00 & 1.00 \\
\hline \multicolumn{7}{|l|}{ Age (years) } \\
\hline $20-44$ & $10(43.5)$ & 1.00 & 1.00 & $21(70.0)$ & 1.00 & 1.00 \\
\hline $45-64$ & $15(48.4)$ & $1.22(0.41-3.57)$ & $1.59(0.48-5.26)$ & $17(65.4)$ & $0.81(0.26-2.5)$ & $0.91(0.27-3.12)$ \\
\hline$\geq 65$ & $21(56.8)$ & $1.69(0.60-5.00)$ & $0.99(0.23-4.17)$ & $9(45.0)$ & $0.35(0.11-1.14)$ & $0.31(0.06-1.61)$ \\
\hline \multicolumn{7}{|l|}{ Chronic problem } \\
\hline Yes & n.a. & n.a. & n.a. & $22(56.4)$ & $0.62(0.24-1.58)$ & $0.51(0.18-1.46)$ \\
\hline No & n.a. & n.a. & n.a. & $25(67.6)$ & 1.00 & 1.00 \\
\hline
\end{tabular}

95\% Cl: 95\% confidence interval; n.a.: not applicable; OR: odds ratio.

\section{Health seeking behavior}

Health seeking behavior has been conceptualized in different ways. Mackian et al. 27 describe the two dominant approaches: pathway models describe the sequence of steps in personal decision making, from perception of a problem to the use of different care types. Determinant models help to understand relations of behavioral choices with personal or societal characteristics 27,28 .

A renowned pathway model is the "health belief model". It sees the decision to utilize a particular service as a personal cost-benefit analysis of the patient 29. This decision is conceptualized as the result of a rational process, in which different elements intervene: the personality of the patient, the perception of the health problem, financial considerations, and the confidence in the health service, including the perception of the doctor's attitude, the perceived technical ability, and - importantly - the perceived accessibility of the service $30,31,32$. While this approach is based on the idea of an individual decision making process, Rogers \& Elliot 33 developed a Network-Episode Model, intending to bridge the individual model with the influence of the social network of the patient, analyzing how choices of health seeking behavior are socially organized.

Andersen and Newman developed a wellknown determinants model to analyze care utilization. They look at societal (available technology, overall accepted norms on health care), health services (existing resources, the concrete organizational setup) and individual (predisposing and enabling factors, perception of illness level) determinants of health seeking behavior 34,35 . Ricketts \& Goldsmith 36 insist on the importance of the dynamics of access as determinant, and developed access models to analyze the potential for individuals and families to learn and modify their behavior and for the health care delivery system to improve its functioning.

In this study, after having determined perceived health problems at community level and their socio-demographic determinants, we analyzed determinants of formal health services uti- 
lization and of the entry point used, completed with a basic analysis of the patient flow within the system.

Of the 312 persons with a health problem over the last month, $68.3 \%$ contacted the formal health system. Our results confirm the absence of differences for the investigated variables for health services use, with only two exceptions. Women with chronic exacerbations tend to contact the health services more readily than men. And for acute health problems, the existence of an underlying chronic illness is of borderline significance for formal health service use.

In comparison to other developing country contexts, the Cuban public health system performs very well 37. In Pakistan, for example, nonavailability of qualified staff, medicines and quality of care compel patients to make multiple visits to multiple doctors for the treatment of the same illness. The quality of care seems to be a main problem in public and private facilities alike 38 . In Nigeria, the main factors determining the use of modern health care services are distance and cost. Cost was the major reason why low income households opted for self-care ${ }^{39}$. In their Burkina Faso study, Mugisha et al. 40 separate health service initiation (with household income, education, urban residence and expected service competency as positive predictors) from service retention, for which only the perceived quality of care has a positive impact.

Cuba has a comprehensive concept of health and of determinants of health, and develops within its economic possibilities - integrated policies for health and well-being of its population 41. As part of this policy, the use of formal health services is actively promoted. The patients' financial possibilities do not play any role to prefer one or another level of service, as all services are free at the point of delivery. Moreover, in this metropolitan study site no differences in geographical accessibility exist.

\section{Entry point to and patient flow in the formal health system}

While the family doctor is expected to be the essential entry point to the health system, this role is fulfilled in only 115 (54\%) of formal system contacts. The family doctor's resolution capacity - i.e. the proportion of patients for which the visit to the family doctor is the end point of their health care for the given sickness episode - is $46.5 \%$ (99/213) of all formal health services contacts. A previous study in the same health area, found contact rates with the family doctor varying between 2.0 and 2.3 contacts per person and per year (cpy) over the period 2004-2008 42. In our study we reach a figure of $1.1 \mathrm{cpy}$. The difference can be explained by service initiated contacts for preventive and periodic follow-ups being included in the 2004-2008 figure.

Cuba is one of the few developing countries where family medicine has a central place in the health care system. Nevertheless, our results indicate that the interpretation of this function remains below expectation. The family doctor combines curative tasks with an important preventive and promotional role, while technical support and first line specialists are concentrated at the first-line policlinic. This organizational setup might explain part of the bypass of the Cuban family doctors. Nevertheless, the high turnover of family physicians is also a problem, as it limits the doctor's knowledge of and identification with her or his community 42 .

Strengths and weaknesses of the actual implementation of the Cuban family doctor model are mainly shaped by three important contextual evolutions. Firstly, compared to the European family doctor, the Cuban model, set up in 1984, has been evolving as new elements in an already well-structured policlinic based model. Family medicine was integrated in the existing first line model, but the old and new logics seem to survive alongside each other. Emergency services at the policlinic (conceptually seen as part of the first line) and at the hospital remain attractive alternatives. Patients easily bypass their family doctor as a result of their perception of needs. Asthma is an obvious example: most patients experiencing an asthma crisis go directly to the emergency services where - contrary to the family doctor cabinet - nebulizers are present 21,22 .

Secondly, economic difficulties since the 1990s had a double effect: authorities put even more emphasis on the pivotal role of family doctors, while economic constraints implied shortages in drugs and medical equipment, which were concentrated at policlinic and hospital level 43 . The limited technical plateau and resolution capacity at the doctor's cabinet remains a problem, e.g. for minor surgery, or for taking samples for laboratory examinations. As a result, a tension developed between the logic of having the patient first visiting his or her family doctor (with a limited technical plateau), and his or her curative needs, making the emergency services and their technical resources more attractive 44 . Today these problems have only partially been palliated.

The third contextual point of relevance is the substantive increase of the international medical collaboration with Venezuela since 200445 . The long term stability of the family doctor in his community was affected, as the need to en- 
sure an adequate coverage of the population of the doctors serving abroad made it necessary to reallocate doctors to other areas and to increase their population of responsibility 42,46 . Therefore, patients might bypass their family doctor because of a long waiting time, the need to visit a doctor after working hours, etc. Only from 2010 onwards sufficient new graduates had left universities to return to a situation of sufficient coverage.

While this situation compromises the entrypoint, coach and synthesis function of the family doctor, health authorities do not consider this a priority problem, as the policlinic is conceived as an essential part of the first line services 19. In the Cuban concept, family doctors have a primarily preventive and supportive objective towards the health of their patients through home visits and a strong link with other sectors in the community. Annually, the family doctor elaborates a community diagnosis of social determinants of health and a plan of how to improve them, and person- ally reviews the health situation of all patients under her or his responsibility.

The growing importance of chronic diseases highlights the need to strengthen the continuity of and specifically the curative role of the family doctor alongside prevention. New research should focus on reinforcing continuity and comprehensiveness of chronic care, possibly by testing group practice models. Attention should also be given to how to strengthen the family doctor's relation with first line specialists and with the technical backstopping at the policlinic.

Finally, since new economic policies have been implemented in Cuba for the last few years, stimulating self-employment and private initiative, in the near future these might increase the strain on the exclusively public health care organization. Nevertheless, over the last half a century the Cuban health system has shown its ability to adapt to new challenges, and basic premises of the Cuban health policy are expected to be preserved.

\section{Contributors}

All the authors contributed equally in the production of the paper.

\section{Acknowledgments}

We thank all voluntary health workers who participated in the interviews for the field study. 


\section{References}

1. Smetana GW, Landon BE, Bindman AB, Burstin $\mathrm{H}$, Davis RB, Tjia J, et al. A comparison of outcomes resulting from generalist vs specialist care for a single discrete medical condition: a systematic review and methodologic critique. Arch Intern Med 2007; 167:10-20.

2. Pongsupap Y, Boonyapaisarnchoaroen T, Van Lerberghe $\mathrm{W}$. The perception of patients using primary care units in comparison with conventional public hospital outpatient departments and 'prime mover family practices': an exit survey. Journal of Health Science 2005; 14:3.

3. Baicker K, Chandra A. Medicare spending, the physician workforce, and beneficiaries' quality of care. Health Aff (Millwood) 2004; Suppl Web Exclusives:W4-184-97.

4. Huber M, Knottnerus JA, Green L, van der Horst H, Jadad AR, Kromhout D, et al. How should we define health? BMJ 2011; 343:d4163.

5. Pan American Health Organization. Estudo regional sobre assistência hospitalar e ambulatorial especializada na América Latina e Caribe. Washington DC: Pan American Health Organization; 2004.

6. World Health Organization. World Health Report 2008: primary health care (now more than ever). Geneva: World Health Organization; 2008.

7. Nutting PA. Population-based family practice: the next challenge of primary care. J Fam Pract 1987; 24:83-8.

8. Longlett SK, Kruse JE, Wesley RM. Communityoriented primary care: historical perspective. J Am Board Fam Pract 2001; 14:54-63.

9. Starfield B, Shi L, Macinko J. Contributions of primary care to health systems and health. Milbank Q 2005; 83:457-502.

10. Ogunlesi TA, Olanrewaju DM. Socio-demographic factors and appropriate health care-seeking behaviour for childhood illnesses. J Trop Pediatr 2010; 56:379-85.

11. Fatimi Z, Avan I. Environmental determinants of utilization of antenatal care in rural settings of Sindh, Pakistan. J Pak Med Assoc 2002; 52:138-42.

12. Chinnakali P, Mohan B, Upadhyay RP, Singh AK, Srivastava R, Yadav K. Hypertension in the elderly: prevalence and health seeking behavior. $\mathrm{N}$ Am J Med Sci 2012; 4:558-62.

13. McCusker J, Karp I, Cardin S, Durand P, Morin J. Determinants of emergency departmentvisits by older adults: a systematic review. Acad Emerg Med 2003; 10:1362-70.

14. Bakeera SK, Wamala SP, Galea S, State A, Peterson S, Pariyo GW. Community perceptions and factors influencing utilization of health services in Uganda. Int J Equity Health 2009; 8:25.

15. Taffa N, Chepngeno G. Determinants of health care seeking for childhood illnesses in Nairobi slums. Trop Med Int Health 2005; 10:240-5.

16. Hosseinpoor AR, Alavian SM, Pharm HJ. Determinants of seeking needed outpatient care in Iran: results from a national health services utilization survey. Arch Iran Med 2007; 10:439-45.
17. Hayward RA, Bernard AM, Freeman HE, Corey CR. Regular source of ambulatory care and acces to health services. Am J Public Health 1991; 81:434-8.

18. de Vos P, Van der Stuyft P. The right to health in times of economic crisis: Cuba's way. Lancet 2009; 374:1575-6.

19. Van der Stuyft P, De Vos P. La relación entre los niveles de atención constituye un determinante clave de la salud. Rev Cubana Salud Pública 2008; 34:1-9.

20. Rojas-Ochoa F, Lopez-Pardo CM. Economy, politics and health status in Cuba. Int J Health Serv 1997; 27:791-807.

21. De Vos P, Vanlerberghe V, Rodriguez A, García R, Bonet M, Van der Stuyft P. Uses of first line emergency services in Cuba. Health Policy 2008; 85:94104.

22. De Vos P, Murlá P, Rodriguez A, Bonet M, Más P, Van der Stuyft P. Shifting the demand for emergency care in Cuba's health system. Soc Sci Med 2005; 60:609-16.

23. García Fariñas A, Rodríguez-Salvá A, De Vos P, Jova Morel R, Bonet Gorbea M, García Roche R, et al. Costos del subsistema de urgencias en la atención primaria de salud en Cuba, 1999-2000. Rev Cubana Salud Pública 2006; 32:1-6.

24. World Health Organization. Global status report on non-communicable diseases 2010. Geneva: World Health Organization; 2011.

25. Martínez Fuentes AJ, Fernández Díaz IE. Ancianos y salud. Rev Cuba Med Gen Integr 2008; 24:4.

26. Ministerio de Salud Pública. Proyecciones de la Salud Pública en Cuba para el 2015. Editorial Ciencias Médicas. La Habana: Ministerio de Salud Pública; 2006.

27. Mackian S, Bedri N, Lovel H. Up the garden path and over the edge: where might health-seeking behaviour take us? Health Policy Plan 2004; 19:137-46.

28. Suchman EA. Stages of illness behaviour and medical care. Journal of Human Health Behaviour 1965; 6:114-22.

29. Jones S, Jones P, Katz J. Compliance in acute and chronic patients receiving a health belief model intervention in the emergency department. Soc Sci Med 1991; 32:1183-9.

30. Irwin D, Jessop EG. Severity of sickness at admission to hospital in Colchester 1985 and 1990. Public Health 1993; 107:171-5.

31. Singh S. Self-referral to accident and emergency department: patients' perception. BMJ 1988; 297: 1179-80.

32. Wood TCA, Cliff KS. Accident and emergency departments - why people attend with minor injuries and ailments. Public Health 1986; 100:15-20.

33. Rogers A, Elliot H. Primary care: understanding health need and demand. Abingdon: Radcliffe Medical Press; 1997.

34. Andersen R, Newman JF. Societal and individual determinants of medical care utilization in the United States. Milbank Q 2005; 83:10.1111/j. 
35. Andersen R. Revisiting the behavioral model and access to medical care: does it matter? J Health Soc Behav 1995; 36:1-10.

36. Ricketts T, Goldsmith L. Access in health services research: the battle of the frameworks. Nurs Outlook 2005; 53:274-80.

37. Cooper RS, Kennelly JF, Orduñez-Garcia P. Health in Cuba. Int J Epidemiol 2006; 35:817-24.

38. Shaikh BT, Hatcher J. Health seeking behaviour and health services utilization trends in National Health Survey of Pakistan: what needs to be done? J Pak Med Assoc 2007; 57:411-4.

39. Amaghionyeodiwe LA. Determinants of the choice of health care provider in Nigeria. Health Care Manage Sci 2008; 11:215-27.

40. Mugisha F, Bocar K, Dong H, Chepng'eno G, Sauerborn R. The two faces of enhancing utilization of health care services: determinants of patient initiation and retention in rural Burkina Faso. Bull World Health Organ 2004; 82:572-9.

41. Iñiguez L. Overview of evolving changes in Cuba's health services. MEDICC Rev 2013; 15:45-51.
42. Guerra M, Rodriguez A, De Vos P, Bonet M, Van der Stuyft P. Ensuring access to first line care in a changing environment: the experience of the Dragones-area in Centro Habana, Cuba (20042007). Trop Med Int Health 2009; 14 Suppl 2:33.

43. De Vos P, García-Fariñas A, Álvarez-Pérez A, Rodríguez-Salvá A, Bonet-Gorbea M, Van der Stuyft $P$. Public health services, an essential determinant of health during crisis. Lessons from Cuba's "special period" (1989-2000). Trop Med Int Health 2012; 17:469-79.

44. De Vos P. "No One Left Abandoned": Cuba's National Health System since the 1959 revolution. Int J Health Serv 2005; 35:189-207.

45. De Vos P, De Ceukelaire W, Bonet M, Van der Stuyft P. Cuba's international cooperation in health: an overview. Int J Health Serv 2007; 37:761-6.

46. De Vos P, Álvarez A, Rodríguez A, Bonet M, Van der Stuyft P. The resilience of Cuba's public health system: how first line health services respond to economic crisis (1990s) and to massive international collaboration (2000s). Trop Med Int Health 2009; 14 Suppl 2:113-4. 


\section{Resumen}

Los servicios de salud de primera línea, o aquellos centrados en la atención primaria, sirven como un fuerte inductor de comportamientos en la búsqueda de cuidados de salud. Estudios sobre la asociación entre la prevalencia de enfermedades crónicas y problemas agudos, y la utilización de servicios de salud, resaltan la importancia de los determinantes socioeconómicos en estos patrones de utilización. Como parte de un estudio transversal con 408 familias en el Centro Habana, Cuba, se realizaron entrevistas domiciliarias entre abril y junio de 2010 para analizar los determinantes sociodemográficos de los problemas de salud agudos y crónicos y el uso de los servicios de salud. Se utilizaron modelos bivariados y de regresión logística. 529 personas relataron la historia de la enfermedad crónica. Durante el mes anterior, 155 de ellas relataron una exacerbación de la enfermedad crónica, y 50 tuvieron algún problema agudo, no relacionado con la enfermedad crónica. 107 personas -sin enfermedad crónica- informaron de problemas agudos. La edad era el principal determinante en la presencia de una enfermedad crónica. Las mujeres adultas y los ancianos presentaban una probabilidad mayor de relatar problemas agudos. Los pacientes con una enfermedad crónica utilizaban los servicios de salud con mayor frecuencia. Ninguna variable sociodemográfica estuvo asociada a la utilización de los servicios o a la consulta con el médico de familia. Pese a que el médico de familia sea definido como la puerta de entrada al sistema de salud, esto ocurría en solamente un $54 \%$ de los pacientes que contactaron con los servicios de salud, por lo que se ve comprometido el papel del médico como consejero y punto de referencia principal sobre las cuestiones de salud de la población. La importancia de las enfermedades crónicas destaca la necesidad de fortalecer el papel esencial del médico de familia. Nuevas políticas económicas en Cuba, con estímulos para la autonomía laboral y la iniciativa privada, podrán aumentar la tensión sobre el sistema de salud exclusivamente público. No obstante, el sistema de salud cubano, ya mostró ser capaz de adaptarse a nuevos desafíos, y se espera que las premisas básicas de la política de salud cubana sean preservadas.

Enfermedad Crónica; Servicios de Salud; Medicina Familiar y Comunitaria

\section{Resumo}

Os serviços de saúde de primeira linha, ou aqueles com uma abordagem de atenção primária, servem como indutor forte de comportamentos de busca de cuidados de saúde. Estudos sobre a associação entre a prevalência de doenças crônicas e problemas agudos e o uso de serviços enfatizam a importância dos determinantes socioeconômicos desses padrões de utilização. Como parte de um estudo transversal de 408 famílias em Centro Habana, Cuba, foram realizadas entrevistas domiciliares entre abril e junho de 2010 para analisar os determinantes sócio-demográficos dos problemas de saúde agudos e crônicos e do uso de serviços de saúde. Foram utilizados modelos bivariados e de regressão logística. Quinhentas e vinte e nove pessoas relatavam história de doença crônica. Durante o mês anterior, 155 delas relataram uma exacerbação da doença crônica e 50 tiveram algum problema agudo, não relacionado à doença crônica. Cento e sete pessoas sem doença crônica referiram problemas agudos. Idade era o principal determinante da presença de doença crônica. As mulheres adultas e os idosos apresentavam probabilidade maior de relatar problemas agudos. Pacientes com doença crônica utilizavam os serviços de saúde com maior frequência. Nenhuma variável sociodemográfica esteve associada à utilização dos serviços ou à consulta com o médico de família. Embora o médico de família seja definido como a porta de entrada ao sistema de saúde, isso ocorria em apenas $54 \%$ dos pacientes que contataram os serviços de saúde, portanto comprometendo o papel do médico como conselheiro e ponto focal das questões de saúde das pessoas. A importância das doenças crônicas enfatiza a necessidade de fortalecer o papel essencial do médico de família. Novas políticas econômicas em Cuba, com estímulo para a autonomia laboral e a iniciativa privada, poderão aumentar a tensão sobre o sistema de saúde exclusivamente público. No entanto, o sistema de saúde cubano já mostrou ser capaz de se adaptar a novos desafios, e espera-se que as premissas básicas da política de saúde cubana sejam preservadas.

Doença Crônica; Serviços de Saúde; Medicina de Família e Comunidade
Submitted on $25 / \mathrm{Jul} / 2014$

Final version resubmitted on 13/Oct/2015

Approved on 16/Oct/2015 